\title{
Organic Food in Public Catering: How the Danish Organic Cuisine Label May Maintain Organic Food Production in the Longer Term
}

\author{
Sørensen, Nina Nørgaard; Sørensen, Marie-Louise Kirchhoff; Trolle, Ellen; Lassen, Anne Dahl
}

Published in:

Journal of Culinary Science \& Technology

Link to article, DOI:

$10.1080 / 15428052.2019 .1582122$

Publication date:

2020

Document Version

Peer reviewed version

Link back to DTU Orbit

Citation (APA):

Sørensen, N. N., Sørensen, M-L. K., Trolle, E., \& Lassen, A. D. (2020). Organic Food in Public Catering: How the Danish Organic Cuisine Label May Maintain Organic Food Production in the Longer Term. Journal of Culinary Science \& Technology, 18(4), 255-269. https://doi.org/10.1080/15428052.2019.1582122

\section{General rights}

Copyright and moral rights for the publications made accessible in the public portal are retained by the authors and/or other copyright owners and it is a condition of accessing publications that users recognise and abide by the legal requirements associated with these rights.

- Users may download and print one copy of any publication from the public portal for the purpose of private study or research.

- You may not further distribute the material or use it for any profit-making activity or commercial gain

- You may freely distribute the URL identifying the publication in the public portal 


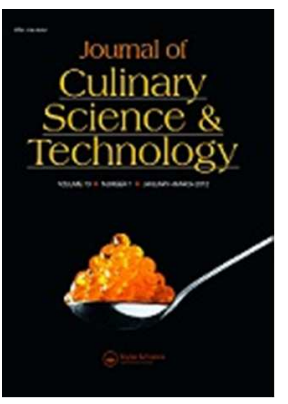

\section{Organic food in public catering: How the Danish Organic Cuisine Label may maintain organic food production in the longer term}

\begin{tabular}{|r|l|}
\hline Journal: & Journal of Culinary Science \& Technology \\
\hline Manuscript ID & Draft \\
\hline Manuscript Type: & Original \\
\hline Keywords: & $\begin{array}{l}\text { Foodservice management, Nutrition, Organic food, Food label, Sustainable } \\
\text { procurement }\end{array}$ \\
\hline \multicolumn{2}{|l}{} \\
\hline
\end{tabular}

\section{SCHOLARONE"}

Manuscripts 


\title{
Introduction
}

16 Organic procurement in public kitchens has a long history over several decades of

17 implementation and development in Denmark, and public awareness of this area has been increasing over time (ICROFS, 2015). More recently, the Danish Organic Action

\begin{abstract}
The aim of this mixed-method longitudinal study was to explore the role the Danish Organic Cuisine Label plays in maintaining organic food production in public catering. Baseline, end-point and 1-year-follow-up were compared among 622 kitchens participating in organic conversion projects. Numbers of certified kitchens increased from baseline to end-point $(\mathrm{p}<0.001)$. This level was maintained at follow-up. Further, certified kitchens were found to increase their use of organic food at 1-year follow-up ( $\mathrm{p}=0.012)$ whereas non-certified kitchens did not. The study identified motives and barriers behind acquiring the label. In conclusion, the Organic Cuisine Label contributed to maintaining organic food productions.
\end{abstract}

Keywords: Organic food conversion; public procurement; Organic Cuisine Label Running head: The Danish Organic Cuisine Label in public catering Plan 2020 was launched in 2012, and updated in 2015, to establish political support for organic food conversion projects targeting public kitchen workers (Ministry of Environment and Food of Denmark, 2015). Organic food conversion projects have been described as educational programs with several steps, in which kitchen workers learn strategies to increase the share of organic food purchased within the existing food budget despite the additional cost of organic food products (Thorsen \& Jensen, 2016; Mikkelsen \& Sylvest, 2012). Besides buying organic food, these strategies include using more fruit and vegetables, limiting meat consumption, using less processed food products, buying local and seasonal food products and reducing food waste (Sørensen et 
28 al., 2015).

29 Evidence on the effects of organic food conversion in public kitchens includes

30 indications of food waste reductions (Thorsen, Sabinsky \& Trolle 2014), a healthier

31 meal composition in favour of plant-based foods and a dietary pattern more in line with

32 food-based dietary recommendations (Mikkelsen et al., 2006; Denver \& Christensen

33 2015). These results are in agreement with recent findings from a longitudinal study on

34 the effects of organic food conversion projects, reporting an emphasis on kitchen

35 worker training in nutrition guideline application (Sørensen et al., 2016a). Regarding

36 kitchen worker physical and psychological well-being during an organic food

37 conversion, no significant negative effects on wellbeing have been found, but rather

38 positive changes were identified in how kitchen workers perceived food quality and

39 their motivation for work (Sørensen et al., 2016b).

40 The longitudinal study on the effects of organic food conversion projects reported a

41 significant increase in organic food percentages among 622 Danish public kitchens with

42 a difference of 24 percentage points over 1.5 years (Sørensen et al., 2016a). The

43 measurement method used was the Organic Cuisine Label method, which was

44 developed by the Danish Veterinary and Food Administration in 2009 for official

45 organic procurement registrations (Danish Veterinary and Food Administration, 2014).

46 This method is based on procurement invoices and has been found to result in valid

47 measurements. Organic procurement levels are divided into four percentage intervals: 0-

$4830 \%$ (no label), 30\%-60\% (bronze label), 60\%-90\% (silver label) and 90\%-100\% (gold

49 label) (Sørensen et al., 2015; Danish Veterinary and Food Administration, 2014).

50 The Organic Cuisine Label is a scheme managed and controlled by the Danish

51 Veterinary and Food Administration with relevance to all public and private large-scale 
1

2

3

4

5

6

7

8

10

52 kitchens and institutions as well as restaurants in Denmark. The label scheme was

53 developed as part of a governmental initiative to promote organic production and

54 consumption on market-driven conditions, as well as in response to the growing need

55 for consumer-oriented documentation of organic food production experienced by large-

56 scale food establishments (Hillgrén et al., 2016; Kortesoja et al., 2018). The Organic

57 Cuisine Label can be awarded to caterers applying for it, if they are able to document

58 calculations of an organic food percentage within one of the three percentage intervals

59 using invoices from suppliers. This organic food percentage level will then be

60 monitored through annual inspections and audits of purchase records by the Danish

61 Veterinary and Food Administration (Danish Veterinary and Food Administration,

62 2014). The Organic Cuisine Label as a scheme has received attention internationally in

63 terms of sustainable food systems and consumer information, and has recently been

64 implemented in Norway and Germany by the private certification schemes Debio and

65 Bioland, respectively (Hillgrén et al., 2016; Kortesoja et al., 2018; Matvalget, 2017;

66 Danish Veterinary and Food Administration, 2018).

67 In Norway, "Valørmerkerne" was implemented by the advisory service called

68 "Matvalget" in 2013, but differs from the Organic Cuisine Label by including food

69 markets in their target group and by requiring a minimum of $15 \%$ organic food

70 production or turnover regarding food markets (Debio, 2017). The German labels

71 recently implemented by Bioland are similar to the Organic Cuisine Labels in terms of

72 percentage intervals but unlike the Danish labels, the eligibility of the Bioland labels is

73 based on a point-system. For public kitchens to achieve a Bioland label, they have to

74 collect points and the more Bioland products of local origin a kitchen includes, the more

75 points they receive (Bioland, 2017; Organic-market.info, 2018). Both the Norwegian

76 and German labels are fairly new compared with the Organic Cuisine Labels, thus no 
77 reports are available their acceptance or influence. Other European countries have also

78 shown interest in implementing the Organic Cuisine Labels, including France and

79 Estonia, but so far, measured effects of organic label schemes outside of Denmark

80 remain to be seen (Danish Veterinary and Food Administration, 2018).

81 Implementing the Organic Cuisine Labels in public kitchens during organic food

82 conversion projects has been suggested to anchor and motivate further organic food

83 production (Sørensen et al., 2016a; NIRAS, 2014). However, there is currently no

84 research supporting this argument because the one existing longitudinal study on the

85 effects of organic food conversion projects did not include measurements taken beyond

861.5 years among the 622 participating kitchens. Hence, the sustainability of the organic

87 conversion projects in public kitchens and the suggested anchoring and motivational

88 effects of applying the Organic Cuisine Label are still unknown.

89 The objectives of this study are therefore to explore official Organic Cuisine Label

90 certifications among 622 public kitchens that participated in the Danish Organic Action

91 Plan 2020 from 2013 to 2015, and to measure the effectiveness of the Organic Cuisine

92 Label certifications on the kitchens' ability to maintain organic food production in the

93 longer term. A further objective is to investigate public kitchen workers' motives behind

94 either acquiring the Organic Cuisine Label or not.

\section{Methods}

\section{Study design and data collection}

97 This longitudinal study applied a mixed-method research design with both qualitative

98 and quantitative data collection methods within a study population of 622 public

99 kitchens that completed organic food conversion from 2013 to 2015 . The kitchens 
100 represent eight different kitchen types according to the classifications by the Danish

101 Diet and Nutrition Association: childcare, school, afterschool, canteen, elderly, hospital,

102 central kitchen or residential institution (Sørensen et al., 2016a; Christiansen \& El-

103 Salanti 2000). Results on distribution of public kitchen types and specific organic food

104 percentages in the public kitchens in 2015 have been published previously (Sørensen et

105 al., 2016a).

106 Data collection was conducted during two stages. The first stage included collecting

107 official certifications of the Organic Cuisine Label among all 622 public kitchens

108 participating in the Danish Organic Action Plan 2020 from 2013 (baseline) to 2015

109 (end-point), and again in 2016 (1-year follow-up). The second stage involved

110 representative samples of Organic Cuisine Label certified kitchens in one group and

111 non-certified kitchens in another group, two subsamples selected from the total of 622

112 kitchens for a semi-structured telephone interview in 2016. The purpose was to gather

113 self-reported data on the actual use of organic procurement as well as qualitative data on

114 the motives behind Organic Cuisine Label certifications and future expectations towards

115 organic procurement. First, a total of 76 public kitchens not certified with the Organic

116 Cuisine Label were selected to represent different kitchen conversion projects, kitchen

117 types and organic procurement levels at endpoint measurements in 2015. A total of 14

118 of the selected kitchens were excluded due to the fact that they had closed, had merged

119 with another kitchen or did not wish to participate, which left a total of 62 participants

120 to be interviewed. Subsequently, 72 public kitchen certified with the Organic Cuisine

121 Label were selected to match the non-certified group according to the same selection

122 criteria listed above, of which a total of 60 could be included in the study. The

123 combined number of public kitchens participating in the telephone interview survey was

124122. 
125 The study was performed in accordance with the ethical standards of the Helsinki

126 Declaration of 1964, as revised in 2013 (World Medical Association, 1974).

\section{Certification with the Organic Cuisine Label}

128 The development of official Organic Cuisine Label certifications among all the 622

129 participating public kitchens was tracked using data from the Danish Veterinary and

130 Food Administration official certification site (Danish Veterinary and Food

131 Administration, 2009) and verified through personal contact with the official

132 certification office. Official certifications were obtained at three points in time: at the

133 beginning of the conversion project period (baseline), at the end of the conversion

134 period (end-point) and again at 1-year follow-up. The 622 public kitchens were grouped

135 into four categories in accordance with the relevant percentage intervals for the Organic

136 Cuisine Label for each measurement point: 1) non-certified and certified kitchens with

137 the following levels 2) gold, 3) silver or 4) bronze.

138 Motives behind acquiring the Organic Cuisine Label

139 Two of the authors interviewed the kitchen managers of the selected public kitchens by

140 telephone using a semi-structured interview guide. Two slightly different interview

141 guides were developed to target either public kitchens certified or not certified with the

142 Organic Cuisine Label. This was done in an effort to allow for potential different

143 reasoning behind acquiring or not acquiring the label, resulting in variations in the

144 interview guides and the following coding. Each telephone interview lasted for

145 approximately 10 to 15 minutes and addressed three main themes: 1) Current organic

146 food procurement and recent developments, 2) Future ambitions for organic food

147 production, 3) Organic Cuisine Label and future development. 
148 Notes were taken during the interviews and the responses were coded afterwards by one

149 of the authors using Template Analysis in Nvivo version 10. Coding of the interviews

150 and the comparative analyses were conducted separately for each group. Interview

151 codes were initially generated based on the interview guides and later elaborated upon

152 following data examination as listed in Table 1, where codes from both interview guides

153 have been included and where the word "reasons" has been used to cover

154 motives/barriers.

\section{Organic food production in the longer term}

156 Self-reported organic food percentages from the non-certified public kitchen sample

$157(n=62)$ and the certified public kitchen sample $(n=60)$ were combined with previously

158 published data to calculate potential differences in actual organic procurement between

159 end-point measurements and 1-year follow-up (Sørensen et al., 2016a). Potential

160 differences in organic food percentages were calculated within each group.

\section{$161 \quad$ Statistical analysis}

162 Non-parametric statistical significance testing of potential differences in specific

163 organic food percentages within the public kitchen samples was made using Wilcoxon

164 signed rank test (paired) along with $1^{\text {st }}$ and $3^{\text {rd }}$ quartiles, as data could not be considered

165 normally distributed. Comparisons were made using chi-squared testing where data

166 were proportions.

167 Statistical analyses were performed using RStudio statistical software package version

$168 \quad 0.98 .1103$ (R Inc., Boston, Massachusetts, USA). 


\section{Results}

\section{Development over time}

171 Official certifications of the Organic Cuisine Label among the 622 public kitchens

172 participating in the Danish Organic Action Plan 2020 from baseline to end-point and at

173 1-year follow-up according to the four categories are illustrated in Figure 1. Overall,

$174553(89 \%)$ of the 622 public kitchens were not certified with any of the three labels at

175 baseline. This number had decreased to $279(45 \%)$ by end-point measurements and at 1-

176 year follow-up, 240 (39\%) of the public kitchens were not certified with an Organic

177 Cuisine Label. Bronze label certifications increased from $18(3 \%)$ at baseline to 102

$178(17 \%)$ at end-point, and remained essentially unchanged at $100(16 \%)$ at 1-year follow-

179 up. Silver label certifications among the 622 public kitchens increased from $38(6 \%)$ at

180 baseline to $183(29 \%)$ at end-point and finally to $221(35 \%)$ at 1-year follow-up.

181 Similarly, gold label certifications increased from $13(2 \%)$ at baseline to $58(9 \%)$ at end-

182 point and reached $61(10 \%)$ at 1-year follow-up (Figure 1). The differences in

183 proportions of Organic Cuisine Label certifications within the four categories from

184 baseline to end-point were significant at $\mathrm{p}<0.001$, but the differences in proportions

185 from endpoint to 1-year follow-up were not (Figure 1).

\section{Organic food production in the longer term}

187 Results of median (interquartile range) organic food percentages among the selected

188 subsamples of interviewed public kitchens from end-point measurements were 64 (55-

189 77) among the public kitchens certified with the Organic Cuisine Label and 55 (42-65)

190 among the public kitchens not certified.

191 The change in organic food percentages from endpoint to 1-year follow-up in the 
192 sample of public kitchens $(n=60)$ certified with Organic Cuisine Label was significant at

$193 \mathrm{p}=0.012$, with an increase from a median (interquartile range) of 64 (55-77) to 68 (53-

194 84) (Table 2). Oppositely, the median (interquartile range) organic food percentages in

195 the sample of public kitchens $(n=62)$ not certified with Organic Cuisine Label decreased

196 non-significantly from 55 (42-65) at end-point to 54 (32-76) at 1-year follow-up (Table

197 2).

198 Motives behind acquiring the Organic Cuisine Label

199 The interviews of public kitchen workers from the subsample of public kitchens not

200 certified with the Organic Cuisine Label $(n=62)$ and from the sample of certified public

201 kitchens $(n=60)$ uncovered different perceptions of the label. The overall motive behind

202 acquiring the Organic Cuisine Label expressed by the majority of respondents from the

203 sample of public kitchens certified with the label focused on kitchen workers' own

204 motivation for obtaining the label. As one kitchen worker elaborated, the Organic

205 Cuisine Label could be considered as the reward kitchen workers receive in return for

206 all of their efforts. Several respondents also mentioned the marketing value of the label,

207 representing a quality mark for the public. This motive was closely followed by requests

208 at the municipal level, where municipalities asked for the implementation of the label.

209 Regarding the sample of public kitchens not certified with the Organic Cuisine Label,

210 four out of five reported a current organic food percentage of $30 \%$ or above and these

211 kitchens would therefore have been eligible for one of the three labels. The two main

212 barriers to acquiring an Organic Cuisine Label expressed by the majority of respondents

213 within this sample were lack of time and the burden of documentation. Most kitchen

214 workers wanted to comply with the documentation requirements of the Organic Cuisine

215 Label but could not find time because of staff shortages and economic supervision of 
216 the institutional management or the municipality. A kitchen worker in a childcare

217 institution clarified that she would rather spend the extra time with the children than

218 performing additional administrative work behind a computer.

219 During the interview, some respondents in the non-certified sample also introduced a

220 shared perception within the public kitchen network in terms of more frequent and

221 stricter control visits by the Danish Veterinary and Food Administration as a

222 consequence of acquiring one of the Organic Cuisine Labels, which prevented them

223 from applying for the label. The same perception was identified among respondents

224 from the sample of public kitchens certified with the Organic Cuisine Label, where

225 some respondents reported acquiring a bronze or silver label rather than gold to

226 minimise the extent of inspections despite gold label eligibility within the public

227 kitchen.

228 Future expectations for organic food production

229 When asked about their future expectations for organic food production in the public

230 kitchen, the vast majority of respondents from both public kitchen samples stated

231 intentions of maintaining the current level of organic procurement. The main barriers

232 identified preventing a further increase in the organic food percentage included

233 economic restrictions, lack of time to explore new organic alternatives and organic food

234 quality limitations. One kitchen worker explained that she would rather support Danish

235 conventional food production than ordering organic products from the other side of the

236 world. Several kitchen workers addressed the problems with documenting organic food

237 procurement from local farmers or from the institution's own organic vegetable garden.

238 Respondents who expressed intentions of increasing the organic food percentage in the

239 future primarily mentioned municipality requests of a higher level in the future and 
240 kitchen workers' own motivation for acquiring the Organic Cuisine Label as the two

241 main underlying motives.

\section{Future expectations for the Organic Cuisine Label}

243 In terms of future ambitions toward the Organic Cuisine Label among the certified

244 public kitchen sample, a few kitchens reported plans to withdraw from the certification

245 due to missing assistance from suppliers in relation to organic food percentage

246 calculations. However, the vast majority planned to maintain their current certification.

247 Among the non-certified public kitchens sample, around one-fifth expressed plans to

248 acquire the label, where the majority of the respondents dismissed plans of obtaining

249 any of the three categories of label. The main reasons stated behind this were time

250 restrictions, problems with fulfilling the perceived documentation and calculation

251 requirements related to the label, along with the lack of knowledge about these

252 requirements. A few respondents also highlighted problems regarding the values

253 connected to the label with one kitchen worker explaining that the organic food

254 percentage in her public kitchen would be eligible for a gold label but acquiring it might

255 be considered boasting within the community.

256 Regarding public kitchens from both sample sets planning to maintain or apply for one

257 of the three Organic Cuisine Labels in the future, more than one-third mentioned

258 positive values related to the label to explain these plans. Several respondents expressed

259 views of the label such as high food quality, views which would then also be transferred

260 to the public kitchen and the institution. But also potential future guidelines by the

261 municipality seemed to influence the kitchen workers' plans. A kitchen worker

262 specifically said that she knew of future municipality guidelines for the label and did

263 not want to apply for the label before the municipality would demand it. 


\section{Discussion}

265 By tracking official Organic Cuisine Label certifications among the 622 public kitchens

266 that participated in the Danish Organic Action Plan 2020 from 2013 to 2015, results

267 from this mixed-method study show an increased number of certifications from baseline

268 to end-point $(\mathrm{p}<0.001)$. This level was sustained at the 1-year follow-up. Regarding the

269 longer term effect on the actual use of organic food, a small but significant increase

$270(\mathrm{p}=0.012)$ in the median organic food percentage was identified among a subgroup of

271 public kitchens certified with the Organic Cuisine Label between end-point and 1-year

272 follow-up, unlike public kitchens not certified with the label.

273 Overall, the results illustrate a trend of increasing numbers of public kitchens acquiring

274 one of the three Organic Cuisine Labels and further, certified public kitchens also wish

275 to acquire higher labels over time. The results on the actual use of organic food also

276 suggest that public kitchens certified with one of the three Organic Cuisine Labels are

277 more likely to maintain or increase their level of organic procurement in the longer term

278 compared with public kitchens not certified with the label. However, when interpreting

279 these results, it is important to note that the median organic procurement levels

280 measured at end-point within the two public kitchen samples are quite similar and both

281 are above $50 \%$. Also, according to self-reported organic food percentages for the 1-year

282 follow-up measurements, more than four out of five of the non-certified public kitchens

283 could be eligible for one of the three Organic Cuisine Labels, illustrating how the use of

284 organic food has been largely sustained, also among kitchens not certified with the

285 Organic Cuisine label.

286 From the interviews, it seems clear that public kitchens are placed within social

287 structures, in which resource allocations for food production are vulnerable to changes 
288 at several levels such as political decisions at municipal level, wishes by parents and

289 other citizens outside the institution, food supply challenges or reorganisations within

290 the institution. Foreseeable changes such as budget reductions or municipal requests for

291 label certification levels are therefore likely to influence kitchen workers' future

292 expectations for the organic food production and label certification whether they are

293 currently certified or not. However, when comparing the two samples, the certified

294 public kitchens expressed stronger views of maintaining their organic food procurement

295 in order to keep their label regardless of future changes, and may therefore have a more

296 stable organic procurement compared with non-certified kitchens. The very few

297 certified public kitchens mentioning a potential withdrawal from the label scheme in the

298 future point to a lack of assistance from food suppliers in calculating the organic food

299 percentage as an explanation for this development.

300 The main motives expressed behind acquiring one of the Organic Cuisine Label relate

301 to kitchen workers' own motivation and requests by the municipality, where the main

302 barriers include time restrictions, heavy documentation requirements and lack of

303 knowledge about the Organic Cuisine Label. The majority of respondents from both

304 samples seem to express willingness towards the label but they seem to differ in how

305 they perceive the workload related to obtaining and maintaining the label. One

306 interpretation might be that the non-certified public kitchens lack knowledge on the

307 details of earning the label and therefore have a tendency to perceive the certification

308 process as too time and resource demanding.

309 Another interpretation involves potential differences in experience with organic food

310 production between the two samples. Expressed views from respondents in both groups

311 indicate that more certified public kitchens had been using organic food before the 
312 Organic Cuisine Label had been introduced compared with the non-certified public

313 kitchens. This additional experience with organic food production may have enabled

314 these kitchens to manage organic food production alongside documentation

315 requirements better. An overall finding from the interviews also relate to the quite

316 different interpretations conveyed by the kitchen workers in terms of the values

317 connected to the Organic Cuisine Labels. Where positive associations regarding

318 signalling the level of food quality and awareness seemed to be agreed upon by the

319 majority, a few respondents also mentioned 'boasting' in a negative way to describe the

320 label and others specified local and seasonal food products to be of top priority over the

321 label and organic food. These views seem to support the need for improved cooperation

322 with food suppliers and information targeting kitchen workers to address the problems

323 faced by many non-certified public kitchens, and thereby to achieve the full potential of

324 the label.

325 Previous research in this area is sparse, but one qualitative study on motives towards

326 organic procurement, including interviews with public kitchen workers from 10

327 different kitchens, also found motives such as kitchen workers' own motivation and

328 political agendas to be important (NIRAS, 2014). This study did not focus on motives

329 behind acquiring the Organic Cuisine Label, but comments from the respondents also

330 compared the label to an award, which is similar to the results from the present study.

331 The previous qualitative study also highlighted the importance of food supplier

332 cooperation and active knowledge sharing about the Organic Cuisine Label to ensure

333 successful implementation of organic procurement, which also relates to the concerns

334 expressed here. Another quantitative study that used an online questionnaire included

335 more than 1000 respondents, which were representative of the Danish population based

336 on gender, age, geography and education, to research population awareness of the 
337 Organic Cuisine Label (Mørk, Tsalis \& Grunert, 2014). The study found overall little

338 awareness of the labels with around $60 \%$ of the respondents having never seen the

339 Organic Cuisine Labels before (Mørk, Tsalis \& Grunert, 2014). Both of these findings

340 call for more information about the labels and the application process targeting public

341 kitchen workers.

342 Regarding the initiatives to improve cooperation between food suppliers and public

343 kitchens, a project on smart procurement has been implemented from 2013 to 2016

344 (Madkulturen, 2016). The aim of the project has been to provide guidance, counselling,

345 tools and case-stories to inspire and promote organic and local food products, targeting

346 all actors within public procurement including politicians, municipalities, kitchens,

347 suppliers and producers (Pedersen \& Jensen, 2016). A qualitative interview study

348 among nine municipal representatives of public procurement evaluated the experienced

349 user satisfaction with the project and found overall support and an ongoing need for it,

350 but also identified barriers to organic and local procurement in terms of political support

351 at higher levels (Pedersen \& Jensen, 2016). In light of the findings from the present

352 study, it may be relevant to recommend implementing renewed efforts in line with this

353 project to ensure wide collaboration across all stakeholders involved in public

354 procurement. This might also enable more efficient and transparent strategies for

355 documenting the level of organic procurement for the Organic Cuisine Label by

356 dividing the specific calculation responsibilities between the stakeholders where

357 appropriate. However, it will be important to ensure that any potential future

358 improvements to the current official documentation and certification process will not

359 carry negative consequences to the label credibility. The Organic Cuisine Label is

360 closely related to the Danish 'Red $\varnothing$ ' which is one of the most recognisable and credible

361 labels in Denmark according to Danish consumers (Danish Competition and Consumer 
362 Authority, 2013; Danish Agricultural and Food Council, 2017), a status worth guarding.

363 A limitation of the study includes the reporting of the level of organic food percentages

364 collected at the 1-year follow-up, due to the fact that is is based on self-reported

365 information, opening up for potential recall bias especially among the non-certified

366 kitchens. A previous study has shown how self-reported estimations of the organic food

367 percentage by public kitchens who do not apply the calculation method behind the

368 Organic Cuisine Label tend to be overestimated (Sørensen et al., 2015). Certified public

369 kitchens may also have an easier time recalling their exact current organic food

370 percentage compared with non-certified public kitchens due to the calculation sheet

371 exercises they complete on a regular basis to fulfil Organic Cuisine Label requirements.

372 The difference in organic food percentages between the two groups (i.e. certified and

373 non-certified) might therefore have been higher than indicated by the present study. In

374 addition, control kitchens that did not participate in the Danish Organic Action Plan

3752020 were not included, which limits the possibility to infer causality regarding the

376 effect of the Organic Cuisine Label on organic procurement in the longer term. In

377 relation to the semi-structured interviews, it would have been ideal to include all 622

378 public kitchens in order to collect indications of the specific organic food percentage

379 within each kitchen.

380 With that said, the population sample included for the quantitative analysis was 622

381 public kitchens and 122 for qualitative analysis, which can be considered a sufficient

382 sample size to explore motives and barriers behind acquiring the Organic Cuisine Label.

383 Further, a strength of the study relates to the matching procedure conducted for the

384 sample selection of the qualitative analysis, which was introduced in an effort to sample

385 as similar populations as possible for the two groups. The overall design, including both 
386 quantitative and qualitative methods, is in addition a strength of the study. The

387 quantitative evaluation uncovered a trend in Organic Cuisine Label development and

388 important results on longer term effects on specific organic food percentages, where the

389 qualitative analysis revealed equally important motives and barriers behind the use of

390 the label. These motives and barriers will be central to address in future initiatives

391 aiming to promote further label certifications by all stakeholders involved in

392 procurement.

\section{Conclusion}

394 To conclude, the present study found an increased number of certifications with the

395 Organic Cuisine Label among the total 622 public kitchens from baseline to end-point

$396(\mathrm{p}<0.001)$ and this level was sustained at 1-year follow-up. A significant increase in

397 median organic food percentages was found in the certified public kitchen sample

$398(\mathrm{n}=60)$, but a small non-significant decrease $(\mathrm{p}=0.053)$ was found in the sample of non-

399 certified public kitchens $(n=62)$ at the 1 -year follow-up. Hence, the results indicate a

400 longer term effect of the Organic Cuisine Label in terms of contributing to a maintained

401 or increased organic food percentage within the public kitchens. Regarding motives

402 behind acquiring the Organic Cuisine Label, kitchen workers' own motivation and

403 requests by the municipality were expressed by the majority of the respondents, where

404 common barriers were time and resource restrictions along with laborious label

405 documentation requirements. Central recommendations for future initiatives promoting

406 further certification of the Organic Cuisine Label are therefore to provide more

407 information about the label and application process, facilitating stronger collaboration

408 with food suppliers and adjusting documentation requirements to minimise the effort

409 where possible. 
410

411 Please see separate file for tables and figure. 


\section{References}

413 International Centre for Research in Organic Food Systems. (2015). Økologiens bidrag

414 til samfundsgoder: vidensyntese 2015 [Organic contributions to public goods:

415 Knowledge Synthesis]. Tjele, Denmark: ICROFS.

416

417 Ministry of Environment and Food of Denmark. (2015). Økologiplan Danmark:

418 sammen om mere økologi [Organic Plan Denmark: Together Towards More Organic].

419 Copenhagen, Denmark: Ministry of Environment and Food of Denmark.

420

421 Thorsen, A. V., \& Jensen, J. D. (2016). Omlaegning til økologi: hvad koster det?

422 [Organic food conversion: how much does it cost?]. Mørkhøj, Denmark: DTU National 423 Food Institute.

424

425

426

427

428

Mikkelsen, B., \& Sylvest, J. (2012). Organic foods on the public plate: technical challenge or organizational change? Journal of Foodservice Business Research, 15(1), 64-83. doi:10.1080/15378020.2011.650541

Sørensen, N. N., Lassen, A., Løje, H., \& Tetens, I. (2015). The Danish Organic Action Plan 2020: assessment method and baseline status of organic procurement in public kitchens. Public Health Nutrition, 18(13), 2350-2357.

doi:10.1017/S1368980015001421

Thorsen, A.V., Sabinsky, M., \& Trolle, E. (2014). Madspild i forbindelse med økologiomlagning i offentlige køkkener [Food Waste During Organic Food Conversion in Public Kitchens]. Søborg, Denmark: DTU National Food Institute. 
438 Mikkelsen, B., Bruselius-Jensen, M., Andersen, J., \& Lassen, A. (2006). Are green

439 caterers more likely to serve healthy meals than non-green caterers? Results from a

440 quantitative study in Danish worksite catering. Public Health Nutrition, 9(7), 846-850.

441 doi:10.1017/PHN2005913

442

443 Denver, S., \& Christensen, T. (2015). Organic food and health concerns: a dietary

444 approach using observed data. NJAS - Wageningen Journal of Life Sciences, 74-75, 9-

445 15. doi:10.1016/j.njas.2015.05.001

446

447 Sørensen, N. N., Tetens, I., Løje, H., \& Lassen, A. (2016a). The effectiveness of the 448 Danish Organic Action Plan 2020 to increase the level of organic public procurement in 449 Danish public kitchens. Public Health Nutrition, 19(18), 3428-3435.

450 doi:10.1017/S1368980016001737

451

452 Sørensen, N. N., Løje, H., Tetens, I., Wu, J. H., Neal, B., \& Lassen, A. (2016b).

453 Wellbeing at work among kitchen workers during organic food conversion in Danish

454 public kitchens: a longitudinal survey. European Journal of Public Health, 26(2), 323455 328. doi:10.1093/eurpub/ckv229

456

457 Danish Veterinary and Food Administration. (2014). Vejledning om økologisk

458 storkøkkendrift [Guidance Report on Organic Procurement in Catering Kitchens].

459 Copenhagen, Denmark: Danish Veterinary and Food Administration. 460 
461 Hillgrén, A., Bröck1, M., Descombes, L., Kontiokari, V., \& Halonen, M. (2016). Nordic

462 Best Practices 2016: Relevant for UNEP 10YFP on Sustainable Tourism and Consumer

463 Information. Copenhagen, Denmark: Nordic Council of Ministers.

464

465 Kortesoja, A., Bröckl, M., Jonsson, H., Kontiokari, V., \& Halonen, M. (2018). Nordic

466 Best Practices 2018: Relevant for UNEP and 10YFP on Sustainable Buildings \&

467 Construction and Sustainable Food Systems. Copenhagen, Denmark: Nordic Council of

468 Ministers.

469

470 Matvalget. (2017). Håndbok for et baerekraftig måltid [Handbook for a sustainable

471 meal]. Bjørkelangen, Norway: Matvalget, DebioInfo.

472

473 Danish Veterinary and Food Administration. (2018). Det økologiske spisemoerke: News

474 [The Organic Cuisine Label: News], (cited 2018 May 7th). Available from:

475 https://www.oekologisk-spisemaerke.dk/nyhed/675-det-okologiske-spisemaerke-

476 kopieret-i-udlandet

477

478 Debio. (2017). Regler for merker og merkebruk [Rules for labels and label-use].

479 Bjørkelangen, Norway: Debio.

480

481 Bioland. (2017). Sie werden kochen vor begeisterung [They will cook with enthusiasm].

482 Mainz, Germany: Bioland.

483

484 Organic-market.info. (2018). Bioland bringt Bio in die Profiküchen [Bioland brings

485 organic food into the professional kitchens], (cited 2018 May $1^{\text {st }}$ ). Available from: 
486 http://bio-markt.info/kurzmeldungen/bioland-bringt-bio-in-die-profikuechen.html

487

488 NIRAS. (2014). Erfaringsopsamling mht. redskaber og undervisningsmateriale til

489 økologiomlcegning $i$ offentlige køkkener [Collection of Experiences Regarding Tools

490 and Educational Materials for Organic Food Converison in Public Kitchens].

491 Copenhagen, Denmark: Danish Veterinary and Food Administration.

492

493 Christiansen, J., \& El-Salanti, N. (2000). På fuldt blus 2000 [Full speed 2000].

494 Copenhagen, Denmark: Centre for Alternative Societal Analysis.

495

496 World Medical Association. (1974). Declaration of Helsinki. Lance, 353, 1418-1419.

497

498 Danish Veterinary and Food Administration. (2009). Det økologiske spisemoerke [The

499 Organic Cuisine Label], (cited 2018 May 7th). Available from: http://www.oekologisk-

500 spisemaerke.dk/

501

502 Mørk, T., Tsalis, G., \& Grunert, K. (2014). Økologi i offentlige køkkener [Organic

503 Food in Public Kitchens]. Tjele, Denmark: DCA - Danish Centre for Food \&

504 Agriculture.

505

506 Madkulturen (2016). Kloge Fødevareindkøb [Smart foodshopping], (cited 2018 May

507 7th). Available from: http://klogefødevareindkøb.dk/

508 
1

2

3

4

5

6

7

8

9

10

11

12

13

14

15

16

17

509 Pedersen, A. B., \& Jensen, A. (2016). Brugerundersøgelse og videreudvikling af

510 rådgivning $i$ kloge fødevareindkøb [User Survey and Development of Guidance in

511 Smart Porcurement]. Aarhus, Denmark: Aarhus University.

512

513 Danish Competition and Consumer Authority. (2013). Analyse af 21 "grønne" moerker:

514 rapport til Miljøstyrelsen og Konkurrence - og Forbrugerstyrelsen 2013 [Analysis of 21

515 'Green' Labels: Report to the Environmental Protection Agency and the Danish

516 Competition and Consumer Authority 2013]. Valby, Denmark: Danish Competition and

517 Consumer Authority.

518

519 Danish Agriculture and Food Council. (2017). Markedsanalyse: danskerne har tillid til

520 Fairtrade-moerket [Marketing analysis: the Danes trust the Fairtrade brand].

521 Copenhagen, Denmark: Danish Agriculture and Food Council. 


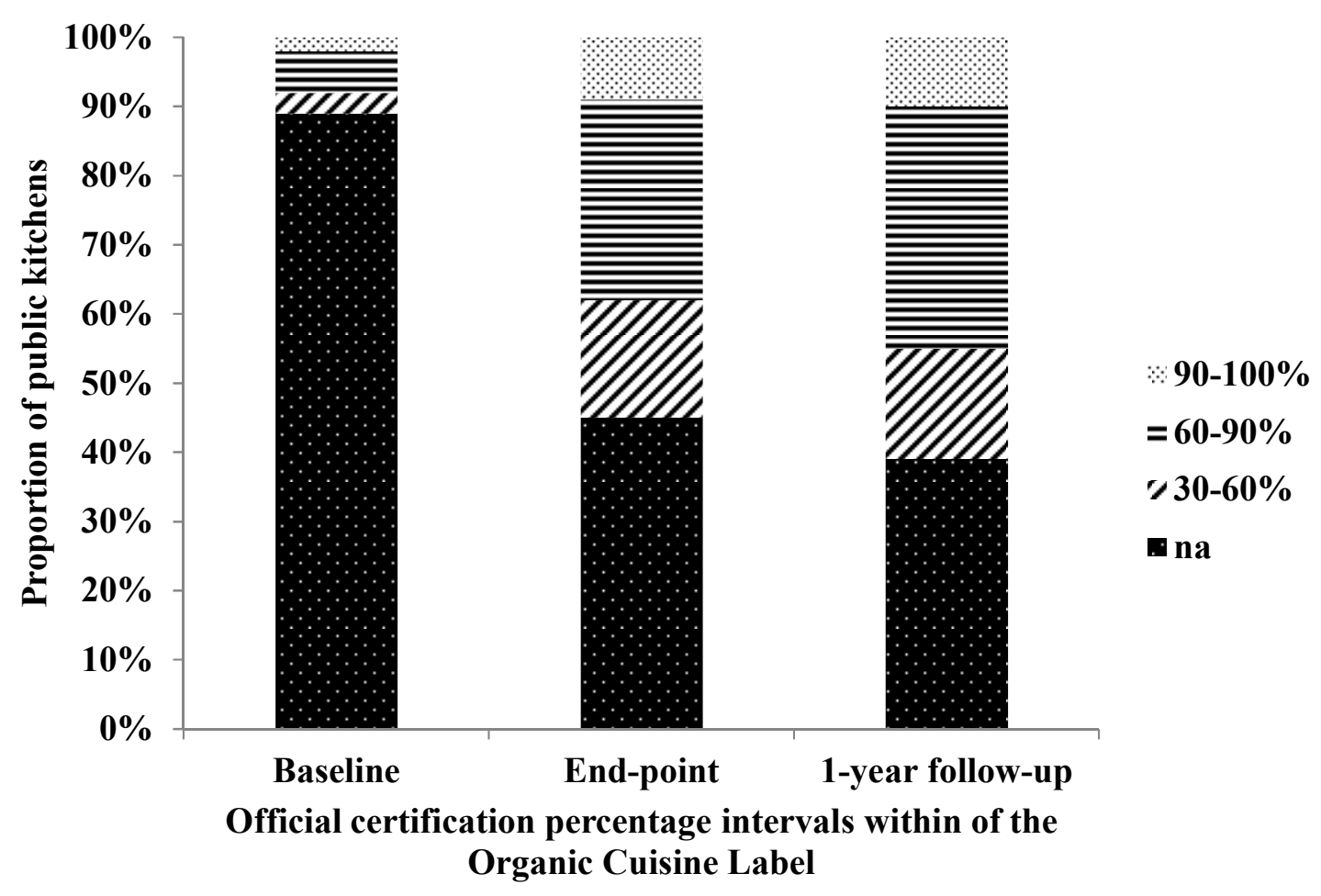

Figure 1. Official Organic Cuisine Label certifications in public kitchens from the Danish Organic Action Plan 2020 measured at baseline, end-point and 1-year follow-up ( $\mathrm{n}=622$ )

*Chi-squared significance test of proportions between measurements at baseline and end-point: $\mathrm{p}<0.001$

*Chi-squared significance test of proportions between measurements at end-point and 1-year follow-up: $\mathrm{p}=0.549$ 
Table 1. Telephone interview coding of interviews among selected subsamples of public kitchens certified and not certified with the Organic Cuisine Label

\begin{tabular}{|c|c|c|}
\hline Level 1 & Level 2 & Level 3 \\
\hline $\begin{array}{l}\text { (1) Current } \\
\text { organic food } \\
\text { procurement and } \\
\text { recent } \\
\text { developments }\end{array}$ & $\begin{array}{l}\text { (1.1) Primary reasons } \\
\text { for increase in organic } \\
\text { food procurement } \\
\text { (1.2) Primary reasons } \\
\text { for decrease in organic } \\
\text { food procurement }\end{array}$ & $\begin{array}{l}\text { (1.1.1) Request from the municipality } \\
\text { (1.1.2) Kitchen workers' own motivation } \\
\text { (1.1.3) Request from institution or others outside the } \\
\text { institution } \\
\text { (1.1.4) Kitchen network } \\
\text { (1.1.5) Organic Cuisine Label } \\
\text { (1.2.1) Kitchen workers lack of motivation } \\
\text { (1.2.2) Not requested from institution or others } \\
\text { outside the institution } \\
\text { (1.2.3) Organic Cuisine Label }\end{array}$ \\
\hline $\begin{array}{l}\text { (2) Future } \\
\text { ambitions for } \\
\text { organic food } \\
\text { production }\end{array}$ & $\begin{array}{l}\text { (2.1) More organic } \\
\text { food } \\
\text { (2.2) No change } \\
\text { (2.3) Less organic } \\
\text { food }\end{array}$ & $\begin{array}{l}\text { (2.1.1) Request from the municipality } \\
\text { (2.1.2) Aim at higher label } \\
\text { (2.2.1) Financial situation } \\
\text { (2.2.2) Supply of organic products } \\
\text { (2.2.3) No documentation for local organic product } \\
\text { (2.3.1) Structural changes } \\
\text { (2.3.2) Financial situation }\end{array}$ \\
\hline $\begin{array}{l}\text { (3) Organic } \\
\text { Cuisine Label and } \\
\text { future } \\
\text { development }\end{array}$ & $\begin{array}{l}\text { (3.1) Primary reasons } \\
\text { for acquiring the label } \\
\text { (3.2) Primary reasons } \\
\text { for not acquiring the } \\
\text { label } \\
\text { (3.3) Future ambitions } \\
\text { for the Organic } \\
\text { Cuisine Label }\end{array}$ & $\begin{array}{l}\text { (3.1.1) Request from the municipality } \\
\text { (3.1.2) Request from the kitchen workers } \\
\text { (3.1.3) Request from institution or others outside the } \\
\text { institution } \\
\text { (3.2.1) Insufficient organic food procurement } \\
\text { (3.2.2) Lack of time to apply } \\
\text { (3.2.3) Heavy documentation load } \\
\text { (3.2.4) Lack of knowledge about the label } \\
\text { (3.3.1) No desire for the label } \\
\text { (3.3.2) Keeping the label }\end{array}$ \\
\hline
\end{tabular}


Table 2. Changes in reported organic food percentages between end-point measurements and 1-year follow-up in the two interviewed subsamples of public kitchens either certified with the official Organic Cuisine Label $(n=60)$ or not certified with the label $(n=62)$

\begin{tabular}{|c|c|c|c|c|c|c|c|}
\hline \multirow[b]{2}{*}{ Quartiles } & \multicolumn{2}{|c|}{ End-point $^{\mathrm{a}}$} & \multicolumn{2}{|c|}{ 1-year follow-up } & \multicolumn{2}{|c|}{ Difference } & \multirow[t]{2}{*}{ P-value } \\
\hline & Median & (IQR) & Median & (IQR) & Median & (IQR) & \\
\hline Registered & 64 & $55-77$ & 68 & $53-84$ & 2 & $-1-8$ & 0.012 \\
\hline Non-registered & 55 & $42-65$ & 54 & $32-76$ & 0 & $-3-12$ & 0.053 \\
\hline
\end{tabular}

